\title{
PERCEPTION OVER E-LEARNING TOOLS IN HIGHER EDUCATION: COMPARATIVE STUDY ROMANIA AND MOLDOVA
}

\author{
Octavian DOSPINESCU \\ Alexandru Ioan Cuza University, Iasi, Romania \\ doctav@uaic.ro \\ Nicoleta DOSPINESCU \\ Alexandru Ioan Cuza University, Iasi, Romania \\ dnicole@uaic.ro
}

\begin{abstract}
Within the article we carry out a comparative scientific research regarding the students' perception of e-learning platforms and tools. The analyzed sample consists of 144 respondents from Romania and the Republic of Moldova who are students of the same university that has several territorial educational centers. In all the territorial centers of education and evaluation, the university uses the same two e-learning platforms: BlackBoard and Moodle. According to previous research in the literature, six significant influencing factors were analyzed. Testing the null hypothesis was performed using the chi-square significance test, which revealed that between the two groups of students there are significant differences on the factors that determine the general perception related to e-learning platforms. Based on the statistical values obtained, we consider that the results are also useful for future research as they highlight that large groups of students from the same university may have totally different perceptions about the same e-learning platforms that are used in the teaching and evaluation process.
\end{abstract}

Keywords: e-learning comparative study, e-learning quality, e-learning student perception JEL classification: I23, D83, L86

DOI: $10.24818 / \mathrm{ie} 2020.02 .01$

\section{Introduction and Literature Review}

Recent research [1] has shown that higher education institutions play an important role in many aspects of our lives. Scientific studies conducted in Europe [2] have shown that universities have a major influence on the development of students' entrepreneurial capacity. To enhance this mission, higher education institutions are trying to adapt to improve the experiences of the beneficiaries of education and to maximize the results of the transfer of knowledge and skills to the entrepreneurial environment. Starting with online business and ending with online volunteering [3], most activities in modern society have an important component based on electronic communication. In the same approach, e-learning systems are currently a common way of transmitting information to the final beneficiaries of different types and ages; at the same time, through the e-learning tools, the complex process of evaluating the knowledge and skills acquired by the learners can be implemented in various ways. Authors in the literature [4] show that traditional learning modalities are rapidly being replaced by those based on new technologies. Recent studies [5] have shown that the use of e-learning technologies in higher education comes with a firm promise that the learning process will have improved performance, despite the fact that there is no clear and sufficient evidence in this regard. At present, the field of e-learning is at the intersection of commercial, educational and technological interests, trying to obtain a dominant position in higher education [6] and it also 
depends on financial issues [7]. Some authors [8] who have analyzed the situation of the universities of South Korea consider that regarding the evaluation of the quality of e-learning systems, at present there is no unanimously accepted assessment method. This is due to the fact that quality attributes have complicated and sometimes unstable relationships.

Being a fashionable paradigm, e-learning has a set of attributes and characteristics that allow comparison and quantification of the results obtained in the learning and evaluation process. Thus, [9] shows that in Oman the main factors that determine the perception on the e-learning tools are the quality of the information, the quality of the services and the degree of complexity of the system. According to [10], the quality of the administrative services associated with the e-learning platform is an important factor. Regarding the concept of e-university, it is confined to the concept of e-learning; the studies conducted by [11] for the universities of Great Britain have shown that the success of an e-university is crucially dependent on the automation of the student evaluation process. The efficiency of this process has a direct impact both on the quality of the educational act and on the perception of the beneficiaries of the distance education system. In Romania, [12] they also analyzed important aspects regarding intellectual capital and knowledge economy.

According to [13], in South America there is a problem in obtaining information about the actual level of use of online platforms and their impact on the educational process in universities. Studies conducted at universities in Asia [14] have shown that students' perception of e-learning platforms is largely dependent on the platform's ability to deliver personalized/customized content according to each user. The possibility of customization has an influence on perceived usefulness and perceived ease-of-use. According to [15], in Vietnam another factor influencing the loyalty of the beneficiaries to the e-learning system refers to the possibility of the students to interact with the online instructor.

Research conducted on the beneficiaries of e-learning systems in North America [16] has shown that the degree of retention of students in online courses depends directly on the existence of course sequences in video format.

\section{Research hypotheses and methodology}

In view of the aspects set out in the specialized literature, we summarize in Table 2 the main factors that influence the students' perception of the e-learning systems. The purpose of this research is to test whether indicators of perception about e-learning tools, such as the quality of information from the e-learning platform, the degree of complexity of the system, the quality of administrative services, the automation of the student evaluation process, the ability of the platform to provide personalized content, the possibility of interacting with the online instructor, the existence of the video sequences in the video format are equally represented among the students from Romania and the Republic of Moldova, so that the obtained results can define a perception model at the level of the Romanian-speaking countries.

Having into consideration the research goal, two research hypotheses are proposed:

Null hypothesis (H0): there isn't any statistically significant correlation between the perception characteristics of the e-learning platforms such as the degree of complexity of the system, the quality of the administrative services, the automation of the student evaluation process, the ability of the platform to provide personalized content, the possibility of interacted with the online instructor, the existence of course sequences in video format and the analyzed countries (Romania and Republic of Moldova).

Alternative hypothesis (H1): there is a statistically significant correlation between the perception characteristics of the e-learning platforms (the degree of complexity of the system, the quality of the administrative services, the automation of the student evaluation process, the ability of the platform to provide personalized content, the possibility to interact with the online 
instructor, the existence of course sequences in video format) and the analyzed countries (Romania and Republic of Moldova).

The research method tests the hypotheses based on the Chi-square test in three stages:

- In the first stage, we calculate $\mathrm{X}^{2}{ }_{0}$ and we compare it with the corresponding value in the statistical chi-square table $\mathrm{X}^{2}(\alpha$, df). We compare these values for different values of $\alpha$ (risk of error): $\alpha=0.01$ and $\alpha=0.05$. The number of degrees of freedom (df) was calculated based on the number of rows $(\mathrm{m})$ and columns $(\mathrm{k})$ in the chi-square analysis, using the formula: $\mathrm{df}=(\mathrm{m}-1) \times(\mathrm{k}-1)$.

- In the second step, if the condition $X^{2}{ }_{(\alpha, d f)}>X^{2}{ }_{0}$ is fulfilled, then the formulated null hypothesis $\mathrm{H}_{0}$ is not supported, while the alternative hypothesis $\mathrm{H}_{1}$ is supported.

- In the third step, the hypotheses are then examined based on the p-value test $(0.01,0.05$, 0.10 ). If the calculated $p$-value is less than 0.01 , then we have strong evidence against the null hypothesis. A p-value between 0.01 and 0.05 means that a moderate evidence exista against the null hypothesis; a p-value between 0.05 and 0.10 means that a plausible evidence exists against the null hypothesis. A p-value greater than 0.10 means that we have no evidence against the null hypothesis.

Data processing and specific calculations were performed with IBM SPSS Statistics version 21.

\section{Results}

The research was carried out on a number of 144 respondents, distributed as follows: 80 respondents from Romania and 64 respondents from the Republic of Moldova. The respondents who answered the questionnaire about perception about e-learning are students of the University Alexandru Ioan Cuza from Iasi, a university that has education centers in both Romania and the Republic of Moldova. Both samples of respondents use the same set of elearning tools in teaching and knowledge assessment activities. Each respondent received a questionnaire stating which influence factor is most important to him. The results are centralized in Table 2.

Table 2. Factors of influence for e-learning platforms

\begin{tabular}{|c|c|c|c|c|c|}
\hline & \multicolumn{2}{|c|}{ Country } & \multirow[t]{2}{*}{ Total } \\
\hline & & & Rep. Moldova & Romania & \\
\hline \multirow{6}{*}{$\begin{array}{l}\stackrel{\circlearrowright}{\Xi} \\
\stackrel{\Xi}{\Xi} \\
\stackrel{\Xi}{\Xi}\end{array}$} & \multirow{2}{*}{$\begin{array}{l}\text { Automation of evaluation } \\
\text { process }\end{array}$} & Count & 4 & 14 & 18 \\
\hline & & $\%$ within Country & $6.3 \%$ & $17.5 \%$ & $12.5 \%$ \\
\hline & \multirow{2}{*}{ Customized content } & Count & 8 & 17 & 25 \\
\hline & & $\%$ within Country & $12.5 \%$ & $21.3 \%$ & $17.4 \%$ \\
\hline & \multirow{2}{*}{$\begin{array}{l}\text { Online tutor/mentor } \\
\text { interaction }\end{array}$} & Count & 21 & 18 & 39 \\
\hline & & $\%$ within Country & $32.8 \%$ & $22.5 \%$ & $27.1 \%$ \\
\hline \multirow{6}{*}{ 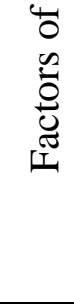 } & \multirow{2}{*}{$\begin{array}{l}\text { Quality of administrative } \\
\text { services }\end{array}$} & Count & 15 & 1 & 16 \\
\hline & & $\%$ within Country & $23.4 \%$ & $1.3 \%$ & $11.1 \%$ \\
\hline & \multirow{2}{*}{ Quality of information } & Count & 5 & 15 & 20 \\
\hline & & $\%$ within Country & $7.8 \%$ & $18.8 \%$ & $13.9 \%$ \\
\hline & \multirow{2}{*}{ Video format content } & Count & 11 & 15 & 26 \\
\hline & & $\%$ within Country & $17.2 \%$ & $18.8 \%$ & $18.1 \%$ \\
\hline \multirow{2}{*}{\multicolumn{2}{|c|}{ Total }} & Count & 64 & 80 & 144 \\
\hline & & $\%$ within Country & $100.0 \%$ & $100.0 \%$ & $100.0 \%$ \\
\hline
\end{tabular}

Source: Authors' analysis 
Testing the null hypothesis regarding the lack of correlation between the country in which the students study and the satisfaction indicators regarding the e-learning platforms using the chisquare test is made on the data group in Table 2.

The indicators regarding the perception about e-learning platforms are considered to be the dependent characteristics in the statistical analysis and the countries for which we conducted the research are consider to be independent characteristics. After performing the chi-square test, we present in Table 3 the synthetic results of the test, the chi-square statistics value and pvalue. The calculated $X^{2}$ value is compared with the reference $X^{2}$ values for $\alpha=0.01$ and $\alpha=$ 0.05 that are obtained from [17].

Table 3. Results and values for Chi-square test calculations

\begin{tabular}{|l|c|c|c|}
\hline & Value & df & p-value \\
\hline Pearson Chi-Square & $25.428^{*}$ & 5 & $0.000^{*}$ \\
\hline $\mathrm{X}^{2}(0.01, \mathrm{df})$ & 15.09 & 5 & \\
\hline $\mathrm{X}^{2}(0.05, \mathrm{df})$ & 11.07 & 5 & \\
\hline Number of Valid Cases & 144 & & \\
\hline
\end{tabular}

Source: Authors' analysis

${ }^{*} \mathrm{p}<0.01$ (evidence to reject $\mathrm{H}_{0}$ )

\section{Discussion}

With the help of the chi-square test we tested the hypothesis of independence of two characteristics. The significance of the chi-square test $\left(\mathrm{X}^{2}{ }_{0}=25.428>\mathrm{X}_{(0.05,5)}=11.07\right.$ and $\left.X^{2}{ }_{0}=25.428>X^{2}(0.01,5)=15.09\right)$ allows us to reject the null hypothesis regarding the independence of these two attributes. As a result, there is a strong correlation between a country and the attributes regarding the perception of e-learning tools in higher education.

The rejection of the null hypothesis is also confirmed by the calculated $p$-value because $p<0.01$, a value which is a strong evidence against the null hypothesis. In addition, this result is also confirmed by the values of contingency coefficient in Table 4.

Table 4. Contingency values

\begin{tabular}{|l|r|r|}
\hline & \multicolumn{1}{|c|}{ Value } & Approx. Sig. \\
\hline Contingency Coefficient & 0.387 & 0.000 \\
\hline N of Valid Cases & 144 & \\
\hline
\end{tabular}

The data obtained allow us to reject the null hypothesis, which means that there is a correlation between the perception of e-learning tools in higher education and the country in which the students learn. This result is even more significant due to the fact that the students are studying at the same university and using the same e-learning platforms, but they come and carry out their educational activities in different countries.

\section{Conclusions}

Based on the statistical data obtained in the research, we can say with a high degree of confidence that the perception of students in Romania and the Republic of Moldova on elearning platforms differs significantly. Thus, there is an obvious correlation between the six determinants (Automation of evaluation process, Customized content, Online tutor/mentor interaction, Quality of administrative services, Quality of information, Video format content) and the countries in which the educational and evaluation process takes place (Romania and Republic of Moldova). 
www.conferenceie.ase.ro

The results obtained are relevant in the light of the fact that the students are enrolled in the same university and use the same e-learning platforms. As a result, based on the results of this study, new research can be developed in the future to analyze the causes that generate this clear difference in perception between students from different countries.

\section{References}

[1] C.-M. Apostoaie, A. Prodan and I.-T. Manolescu, "R\&D Projects as Instruments for Enhacing Gender Equality in Universities," Anduli, no. 18, pp. 199-218, 2019.

[2] R. D. Nitu-Antonie and E.-S. Feder, "The Role of Economic Academic Education on Entrepreneurial Behavior," Amfiteatru Economic, vol. 17, no. 38, pp. 261-276, 2015.

[3] D. Danaiata, D. C. Gligor-Cimpoieru, L. Hurbean and V. Munteanu, "The Potential of Employees Online Volunteering in Romania," in Proceedings of the 7th International Management Conference: New Management for the New Economy, Bucharest, 2013.

[4] A.-M. G. Petrasuc and D. Popescul, "The Dark Side of Digitalization: Information and Communication Technology Influence on Human Learning Processes," in New Technologies and Redesigning Learning Spaces, VOL II, Bucharest, 2019.

[5] T. Goodchild and E. Speed, "Technology enhanced learning as transformative innovation: a note on the enduring myth of TEL," Teaching in Higher Education, vol. 24, no. 8, pp. 948-963, 2019.

[6] D. Popescul, V.-D. Pavaloaia, A. Tugui, M. Georgescu, L.-D. Radu and L. D. Berechet, "Education by Choice, Not by Chance: Adjustement of Business Education to the Requirements of Contemporary Organisations," Transformations in Business \& Economics, vol. 15, no. 3C, pp. 452-477, 2016.

[7] D.-T. Agheorghiesei, S. G. Anton and D. Airinei, "The Impact of Financial Crisis on the Quality of Higher Education System. An Exploratory Study from the Perspective of the Vulnerability Perceived by the Students," Transformations in Business \& Economics, vol. 17, no. 2B, pp. 721-737, 2018.

[8] C.-R. Choi and H.-Y. Jeong, "Quality evaluation for multimedia contents of e-learning systems using the ANP approach on high speed network," Multimedia Tools and Applications, vol. 78, no. 20, pp. 28853-28875, 2019.

[9] S. Al Zoubi and A. Alzoubi, "E-learning Benchmarking Adoption: A Case Study of Sur University College," International Journal of Advanced Computer Science and Applications, vol. 10, no. 11, pp. 463-470, 2019.

[10] L. Pham, K. Kim, B. Walker, T. DeNardin and H. Le, "Development and Validation of an Instrument to Measure Student Perceived E-Learning Service Quality," International Journal of Enterprise Information Systems, vol. 15, no. 2, pp. 15-42, 2019.

[11] R. Ismail, F. Safieddine and A. Jaradat, "E-university delivery model: handling the evaluation process," Business Process Management Journal, vol. 25, no. 7, pp. 1633-1646, 2019.

[12] A. S. Nestian, S. Tita and A. L. Guta, "Intensity of Involvement of Teachers and Researchers from Romanian Universities in Bioeconomy Knowledge Flows," Amfiteatru Economic, vol. 20, no. 49, pp. 567-582, 2018.

[13] M. Peralta, "Business Intelligence in E-learning, a case study of an Ecuadorian University," in 2018 XIII Latin American Conference on Learning Technologies (LACLO 2018), 2019.

[14] C.-Y. Chiang, K. Boakye and X. Tang, "The Investigation of E-Learning System Design Quality on Usage Intention," Journal of Computer Information Systems, vol. 59, no. 3, pp. 256-265, 2019. 
www.conferenceie.ase.ro

[15] L. Pham, Y. Limbu, T. Bui, H. Nguyen and H. Pham, "Does e-learning service quality influence e-learning student satisfaction and loyalty? Evidence from Vietnam," International Journal of Educational Technology in Higher Education, vol. 16, no. 7, 2019.

[16] S. Gupta and A. Sabitha, "Deciphering the attributes of student retention in massive open online courses using data mining techniques," Education and Information Technologies, vol. 24, no. 3, pp. 1973-1994, 2019.

[17] T. U. o. T. a. Austin, "Table of Chi-square statistics," The University of Texas at Austin, Texas, 2020. 